\title{
Studies on the Sulfur-containing Chelating Agents. XXXI.1) Catalytic Effect of Copper (II) Ion to Formation of Mixed Disulfide
}

\author{
Hiromu Sakurai, Akira Yokoyama and Hisashi Tanaka \\ Faculty of Pharmaceutical Sciences, Kyoto University ${ }^{2}$ )
}

(Received January 5, 1971)

\begin{abstract}
In order to discuss the possibility of the contribution of the chelating ability to the radioprotective activity in cysteamine, effects of copper (II) ion to the formation of the mixed disulfide was investigated in the systems of cysteamine and cysteine, glutathione and albumin respectively as the reactions between two kinds of thiol compound and in the system of cystamine and cysteine as the reaction between disulfide and thiol compound by the use of ${ }^{35} \mathrm{~S}$-cysteamine or ${ }^{14} \mathrm{C}$-cysteine. Separations of the mixed disulfides were achieved by electrophoresis and amounts of the mixed disulfides were estimated by the measurement of radioactivity. Remarkable catalytic effects were observed depending upon the reaction conditions. Whereas inhibitive effects were observed in some cases. Relationship between the effect of copper (II) ion and the reaction condition was discussed and an intermediate copper chelate was presumed for the reaction mechanism.
\end{abstract}

Formation of mixed disulfide is considered to be an important reaction in connection with the biochemical function of thiols and it has been presumed as one of the possible mechanisms of the radioprotectors which contain thiol group. ${ }^{\mathbf{3} 4)}$ In addition, chelate formation with metal ions has also been presumed as an important factor in the mechanism of the radioprotective activity. ${ }^{5-9}$ ) It has been advocated in these presumptions that thiol group which is sensitive to the radiation damage in protein is protected by the formation of the mixed disulfide with the radioprotective thiol compounds, ${ }^{5)}$ and in addition the valence state of the metal in the metalloenzyme is kept unchanged through the complex formation with the radioprotective compounds against the oxidation caused by the radiation. ${ }^{7}$ Various experimental supports for the above-mentioned presumptions have been reported, but the formation of the mixed disulfide and the chelate formation have not been treated in mutual connection as to the mechanism of the radioprotective activity. Recently Williamson mentioned briefly the catalytic effect of copper ion to the formation of the mixed disulfide in the thiol-disulfide exchange reaction of cystine- $\beta$-globulins system, ${ }^{10)}$ but the effect of the metal ion to the formation of the mixed disulfide from two kinds of thiol compound has not been investigated. We have studied on the complex formation of cysteamine which has been known as one of the most potential radioprotectors and its derivatives for the investigation of the relationship between the complex formation and the radioprotective activity. In the previous paper, ${ }^{\mathbf{1 1}}$ we reported the complex formation of cysteamine the copper which is

1) Part XXX: Y. Sugiura and H. Tanaka, Mol. Pharmacol., submitted.

2) Location: Yoshida Shimoadachi-cho, Sakyo-ku, Kyoto.

3) L. Eldjarn and A. Pihl, "Mechanisms in Radiobiology," 2 ed. by M. Errera and A. Forssberg, Academic Press, New York,1961, p. 231.

4) A. Pihl and T. Sanner, Radiation Res., 19, 27 (1963).

5) Z.M.Bacq, "Chemical Protection Againt Ionizing Radiation," Charles C Thomas Publisher, Springfield, Illinois, U.S.A., 1965, p. 39.

6) W. Lohmann, Progr. Biochem. Pharmacol., 1, 118 (1965).

7) W.O.Foye and J. Mickles, Progr. Biochem. Pharmacol., 1, 152 (1965).

8) J. Schubert, Nature, 200, 375 (1963).

9) W. Lohmann, M. Momeni and P. Nette, Strahlentherapie, 134, 590 (1967).

10) M.B. Williamson, Biochem. Biophys. Res. Comm., 39, 379 (1970).

11) H. Sakurai, A. Yokoyama and H. Tanaka, Chem. Pharm. Bull. (Tokyo), 18, 2373 (1970). 
one of the most important metals as to the biochemical redox system. As some kinds of metal ion may have catalytic effect to the formation of the mixed disulfide, we have investigated the effect of copper ion to the formation of the mixed disulfide on the systems of cysteaminecysteine (A), cysteamine-glutathione (B), cysteamine-albumin (C), and cystamine-cysteine (D).

\title{
Experimental
}

\begin{abstract}
Materials_C Cysteamine $\cdot \mathrm{HCl}$, L-cysteine and $\mathrm{CuCl}_{2} \cdot 2 \mathrm{H}_{2} \mathrm{O}$ were purchased from Nakarai Chemicals. Cystamine $\cdot 2 \mathrm{HCl}$ was synthesized according to Foye's method. ${ }^{12}$ ) Glutathione and bovine serum albumin was purchased from Kohjin Co., Ltd. and Sigma Chemical Co. respectively. ${ }^{14} \mathrm{C}-\mathrm{L}-\mathrm{Cysteine} \cdot \mathrm{HCl}$ and ${ }^{35} \mathrm{~S}-$. cysteamine were obtained from The Radiochemical Center. Other reagents used were of reagent grade.

Apparatus-Paper electrophoresis was carried out on a Toyo filter paper No. 50 by a Yanagimoto. paper electrophoresis Model EC-10. Radioactivity was measured and recorded by a Fujitsu chromatobeta analyzer Model EA-120, Fujitsu linear count rate meter model RM-90 and Toa electronic polyrecorder model EPR-2TB. Absorption spectra in visible region were measured by Hitachi EPS-2 recording spectrophotometer.

Procedure- $-{ }^{35}$ S-Cysteamine was allowed to react with equimolar quantities of cysteine, and glutathione and bovine serum albumin respectively under various conditions ( $\mathrm{pH} 3.9$ acetate buffer, $\mathrm{pH} 7.4 \mathrm{phos}-$. phate buffer, and $\mathrm{pH} 10.9$ borate buffer) in the presence of various amount of $\mathrm{Cu}$ (II) ion (equi, 0.1 and 0.01 molar quantities). Concentrations of thiols were $1 \times 10^{-2} \mathrm{M}, 5 \times 10^{-3} \mathrm{M}$ and $5 \times 10^{-4} \mathrm{M}$ in the systems (A), (B) and (C) respectively. The reaction mixtures were kept at $37^{\circ}$. The aliquots taken from the reaction mixtures which were allowed to stand for $0.5,2$ or $24 \mathrm{hr}$, were acidified to $\mathrm{pH} 2.5$ by the addition of glacial acetic acid, and the mixed disulfides were separated by the electrophoresis with $2 \%$ acetic acid as an electrolyte and voltage gradient $1000 \mathrm{~V}, 15 \mathrm{~min}$ for systems (A), (B) and (C). The radioactivity from the spots of the mixed disulfide were measured and the result obtained in the presence of $\mathrm{Cu}$ (II) ion was compared with that obtained in the absence of $\mathrm{Cu}$ (II) ion. The similar experiments were carried out in system (D) for the comparative study by the use of ${ }^{14} \mathrm{C}$-cysteine $\left(1 \times 10^{-2} \mathrm{M}, 1000 \mathrm{~V}, 20 \mathrm{~min}\right)$. The bands of the mixed disulfides were confirmed by the identification of thiols which were produced by the reaction with excess mercaptoethanol. ${ }^{13)}$ The effects of other metal ions such as $\mathrm{Mg}$ (II), Cr (III), Mn (II), Fe (III), Co (II), Ni (II), $\mathrm{Zn}$ (II), $\mathrm{Cd}$ (II) and $\mathrm{Hg}$ (II) were examined by the similar procedure to that in system (A).
\end{abstract}

\section{Result and Discussion}

In systems (A) and (B), the mixed disulfides were detected as well separated spots which appeared between those of two different symmetrical disulfides. Under the experimental conditions adopted here, remaining thiol compounds were not separated from corresponding. symmetrical disulfides. In system (B), when equimolar quantity of copper (II) ion is present the formation of a compound which is different from cysteamine-glutathione mixed disulfide. was observed in any reaction medium and the amount of the compound increased with time. This compound was considered from its electrophoretic mobility to be cysteamine-cysteine mixed disulfide which was produced by the hydrolysis of glutathione. In system (C), all the radioactivity of ${ }^{35} \mathrm{~S}$ from cysteamine was detected on the band of albumin, which was. confirmed by the detection with ninhydrin, ${ }^{\mathbf{1 4})}$ and that of cystamine. This fact shows that cysteamine-albumin mixed disulfide and albumin have the same electrophoretic mobility. The electropherograms of systems (B) and (C) are shown in Fig. 1 and 2.

The effects of the copper (II) ion are summarized in Tables I and II. Remarkable catalytic effects were observed under various conditions while inhibitory effects were observed in some cases and the relationship between the reaction condition and the catalytic effect can not be explained simply. However, the influence of the reaction condition towards the effect of copper (II) ion and the characteristics of the reactions in these systems may be explained. as follows through the patterns of the effects of copper (II) seen in Fig. 3.

12) W.O. Foye, A.M. Hebb and J. Mickles, J. Pharm. Sci., 56, 292 (1967).

13) N.J.J. van Rensburg and O.A. Swanepoel, Arch. Biochem. Biophys., 118, 531 (1967).

14) E.W. Yemm and E.C. Cocking, Analyst, 80, 209 (1955). 


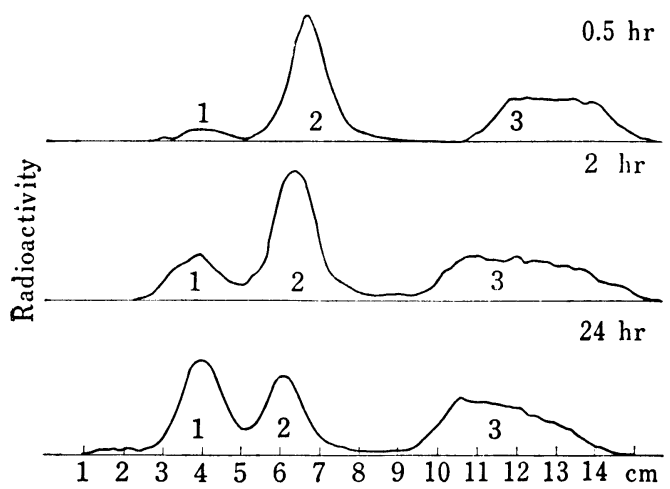

Fig. 1. Paper Electrophoresis of CysteamineGlutathione-Copper

1: cysteamine-cysteine mixed disulfide

2: cysteamine-glutathione mixed disulfide

3: cysteamine and cystamine

cysteamine: glutathione: $\mathrm{Cu}(\mathrm{II})=1: 1: 1$ pH 7.4

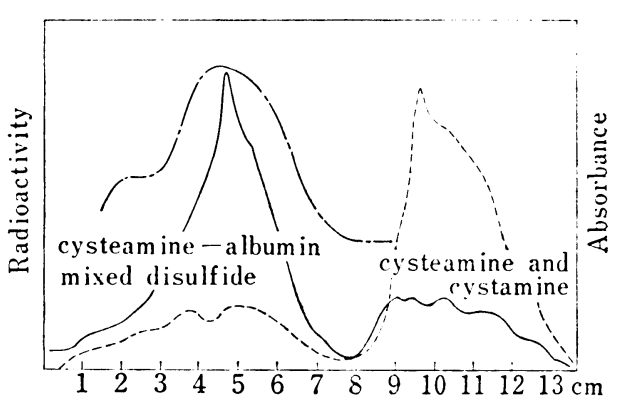

Fig. 2. Paper Electrophoresis of CysteamineAlbumin-Copper

albumin: cysteamine: $\mathrm{Cu}(\mathrm{II})=1: 1: 0(\mathrm{pH} 3.9)$

albumin: cysteamine: $\mathrm{Cu}(\mathrm{II})=1: 1: 0.01$ (pH 7.4)

-.-.-: albumin (by ninhydrine)

(B) cysteamine-gluta thione

(A) cysteamine-cysteine

cysteamine : cysteine : $\mathrm{Cu}(\mathrm{II})=$

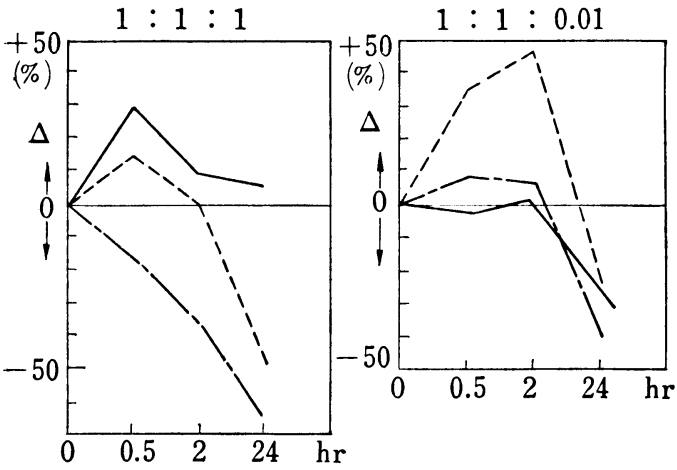

(C) cysteamine-albumin

cysteamine : albumịn: $\mathrm{Cu}(\mathrm{II})=$

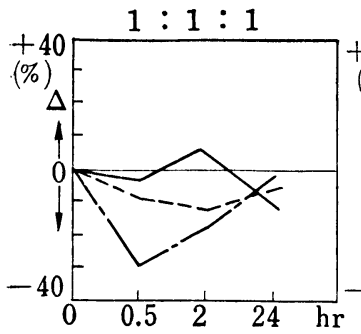

$1: 1: 0.01$

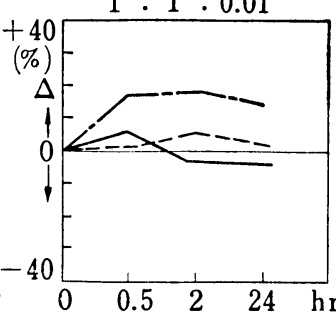

cysteamine : glutathione : $\mathrm{Cu}$ (II) $=$
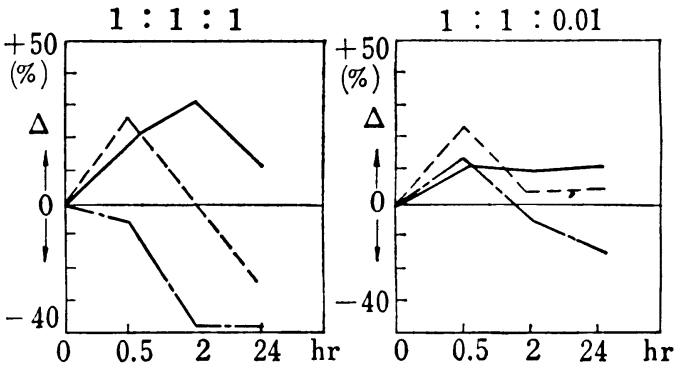

The values of $\Delta$ in system $B$ represent the amount of cysteamine-glutathione mixed disulfide.

(D) cystamine-cysteine

cystamine : cysteine : $\mathrm{Cu}(\mathrm{II})=$

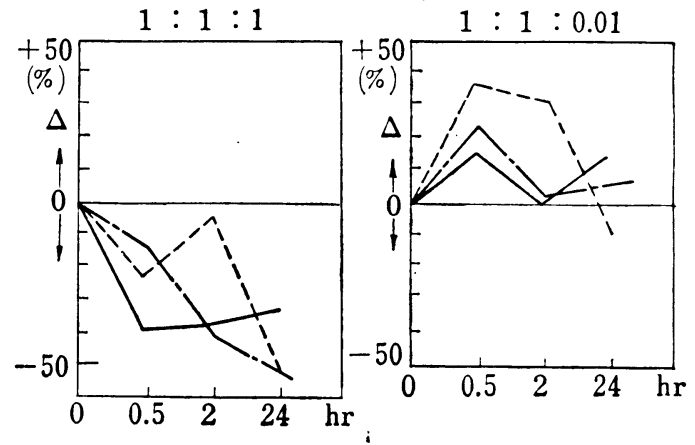

Fig. 3. Comparison of the Effect of Copper (II) Ion

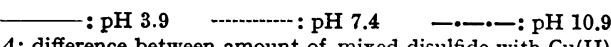

$\Delta$ : difference between amount of mixed disulfide with $\mathrm{Cu}(\mathrm{II})$

and that without $\mathrm{Cu}(\mathrm{II})$ 
TABLE I. Catalytic Effect of Copper (Percentage of Radioactivity of Mixed Disulfide in Total Radioactivitity)

A) Cysteamine-Cysteine

\begin{tabular}{|c|c|c|c|c|c|c|c|c|c|c|c|c|c|}
\hline \multirow{2}{*}{$\begin{array}{r}\text { System } \\
\mathrm{pH}\end{array}$} & & \multicolumn{3}{|c|}{$\begin{array}{l}\text { Cysteamine } \\
\text { cysteine }\end{array}$} & \multicolumn{3}{|c|}{$\begin{array}{c}\text { Cysteamine } \\
\text { cysteine } \\
\text { equimolar } \mathrm{Cu}(\mathrm{II})\end{array}$} & \multicolumn{3}{|c|}{$\begin{array}{c}\text { Cysteamine } \\
\text { cysteine } \\
0.1 \text { molar } \mathrm{Cu}(\mathrm{II})\end{array}$} & \multicolumn{3}{|c|}{$\begin{array}{c}\text { Cysteamine } \\
\text { cysteine } \\
0.01 \text { molar } \mathrm{Cu}(\mathrm{II})\end{array}$} \\
\hline & & 3.9 & 7.4 & 10.9 & 3.9 & 7.4 & 10.9 & 3.9 & 7.4 & 10.9 & 3.9 & 7.4 & 10.9 \\
\hline $\begin{array}{l}\text { Reaction } \\
\text { time (hr) }\end{array}$ & $\begin{array}{l}0.5 \\
2 \\
24\end{array}$ & $\begin{array}{l}25.3 \\
29.5 \\
35.2\end{array}$ & $\begin{array}{l}19.6 \\
21.1 \\
62.8\end{array}$ & $\begin{array}{l}44.8 \\
50.5 \\
73.9\end{array}$ & $\begin{array}{l}54.7 \\
38.9 \\
40.4\end{array}$ & $\begin{array}{l}33.1 \\
20.8 \\
16.2\end{array}$ & $\begin{array}{r}30.3 \\
14.5 \\
7.1\end{array}$ & $\begin{array}{l}46.2 \\
41.9 \\
43.8\end{array}$ & $\begin{array}{l}56.9 \\
49.5 \\
38.6\end{array}$ & $\begin{array}{l}54.8 \\
34.0 \\
48.0\end{array}$ & $\begin{array}{r}24.5 \\
30.4 \\
9.8\end{array}$ & $\begin{array}{l}53.5 \\
68.0 \\
40.3\end{array}$ & $\begin{array}{l}53.8 \\
57.9 \\
37.6\end{array}$ \\
\hline
\end{tabular}

B) Cysteamine-Glutathione

\begin{tabular}{|c|c|c|c|c|c|c|c|c|c|c|}
\hline \multicolumn{2}{|l|}{ System } & \multicolumn{3}{|c|}{$\begin{array}{l}\text { Cysteamine } \\
\text { glutathione }\end{array}$} & \multicolumn{3}{|c|}{$\begin{array}{c}\text { Cysteamine glutathione } \\
\text { equimolar } \mathrm{Cu}(\mathrm{II})\end{array}$} & \multicolumn{3}{|c|}{$\begin{array}{l}\text { Cysteamine glutathione } \\
0.01 \text { molar } \mathrm{Cu}(\mathrm{II})\end{array}$} \\
\hline \multirow[t]{2}{*}{$\mathrm{pH}$} & & 3.9 & 7.4 & 10.9 & 3.9 & 7.4 & 10.9 & 3.9 & 7.4 & 10.9 \\
\hline & 0.5 & 22.6 & 22.8 & 31.7 & $\begin{array}{c}37.6 \quad 3.1^{a)} \\
40.7\end{array}$ & $\begin{array}{c}48.77_{56.3} \\
\end{array}$ & $\begin{array}{c}25.528 .3^{a)} \\
53.8\end{array}$ & 35.4 & $\begin{array}{l}47.91 .1^{a)} \\
49.0\end{array}$ & $\begin{array}{l}44.23 .2^{a)} \\
47.4\end{array}$ \\
\hline \multirow[t]{2}{*}{$\begin{array}{l}\text { Reaction } \\
\text { time (hr) }\end{array}$} & 2 & 16.7 & 42.8 & 49.9 & $\begin{array}{c}47.33^{3.5^{a)}} \\
50.8\end{array}$ & $\begin{array}{l}42.815 .5^{a)} \\
58.3\end{array}$ & $\begin{array}{c}10.477 .4^{a)} \\
88.1\end{array}$ & 26.7 & $\begin{array}{l}46.71 .7^{a)} \\
48.4\end{array}$ & $\begin{array}{l}45.82 .8^{a)} \\
48.6\end{array}$ \\
\hline & 24 & 28.4 & 48.8 & 48.7 & $\begin{array}{c}39.44 .4^{a)} \\
43.8\end{array}$ & $\begin{array}{c}\left.25.232 .9^{a}\right) \\
58.1\end{array}$ & $\begin{array}{l}9.382 .8^{a)} \\
92.1\end{array}$ & 40.8 & $\begin{array}{l}54.51 .3^{a)} \\
55.8\end{array}$ & $\begin{array}{l}36.46 .8^{a)} \\
43.2\end{array}$ \\
\hline
\end{tabular}

a) Values represent those for cysteamine-cysteine mixdied disulfide.

C) Cysteamine-Albumin

\begin{tabular}{|c|c|c|c|c|c|c|c|c|c|c|}
\hline \multirow{2}{*}{$\begin{aligned} \text { System } \\
\mathrm{pH}\end{aligned}$} & & \multicolumn{3}{|c|}{$\begin{array}{l}\text { Cysteamine } \\
\text { albumin }\end{array}$} & \multicolumn{3}{|c|}{$\begin{array}{l}\text { Cysteamine albumin } \\
\text { equimolar } \mathrm{Cu}(\mathrm{II})\end{array}$} & \multicolumn{3}{|c|}{$\begin{array}{l}\text { Cysteamine albumin } \\
0.01 \text { molar } \mathrm{Cu}(\mathrm{II})\end{array}$} \\
\hline & & 3.9 & 7.4 & 10.9 & 3.9 & 7.4 & 10.9 & 3.9 & 7.4 & 10.9 \\
\hline $\begin{array}{l}\text { Reaction } \\
\text { time (hr) }\end{array}$ & $\begin{array}{l}0.5 \\
2 \\
24\end{array}$ & $\begin{array}{l}23.7 \\
14.8 \\
24.3\end{array}$ & $\begin{array}{l}75.5 \\
80.0 \\
81.2\end{array}$ & $\begin{array}{l}83.2 \\
81.6 \\
80.4\end{array}$ & $\begin{array}{r}21.1 \\
19.5 \\
.14 .8\end{array}$ & $\begin{array}{l}67.0 \\
67.5 \\
74.6\end{array}$ & $\begin{array}{l}53.3 \\
64.3 \\
78.0\end{array}$ & $\begin{array}{l}30.1 \\
12.6 \\
21.6\end{array}$ & $\begin{array}{l}77.2 \\
85.9 \\
83.5\end{array}$ & $\begin{array}{c}100 \\
100 \\
95.8\end{array}$ \\
\hline
\end{tabular}

D) Cystamine-Cysteine

\begin{tabular}{|c|c|c|c|c|c|c|c|c|c|c|c|c|c|}
\hline \multirow{2}{*}{$\begin{array}{r}\text { System } \\
\mathrm{pH}\end{array}$} & & \multicolumn{3}{|c|}{$\begin{array}{l}\text { Cystamine } \\
\text { cysteine }\end{array}$} & \multicolumn{3}{|c|}{$\begin{array}{c}\text { Cystamine } \\
\text { cysteine } \\
\text { equimolar } \mathrm{Cu}(\mathrm{II})\end{array}$} & \multicolumn{3}{|c|}{$\begin{array}{c}\text { Cystamine } \\
\text { cysteine } \\
0.01 \text { molar } \mathrm{Cu}(\mathrm{II})\end{array}$} & \multicolumn{3}{|c|}{$\begin{array}{c}\text { Cystamine } \\
\text { cysteine } \\
0.01 \text { molar } \mathrm{Cu}(\mathrm{II})\end{array}$} \\
\hline & & 3.9 & 7.4 & 10.9 & 3.9 & 7.4 & 10.9 & 3.9 & 7.4 & 18.9 & 3.9 & 7.4 & 10.9 \\
\hline \multirow{3}{*}{$\begin{array}{l}\text { Reaction } \\
\text { time (hr) }\end{array}$} & 0.5 & 49.5 & 43.1 & 46.3 & 10.0 & 19.7 & 34.1 & 48.9 & 65.4 & 60.3 & 64.1 & 78.4 & 69.5 \\
\hline & 2 & 49.1 & 38.5 & 68.5 & 11.9 & 31.5 & 28.0 & 45.2 & 63.6 & 53.9 & 48.7 & 69.9 & 69.8 \\
\hline & 24 & 45.4 & 69.1 & 67.8 & 14.3 & 19.6 & 14.6 & 62.7 & 76.2 & 63.5 & 59.5 & 61.1 & 74.6 \\
\hline
\end{tabular}

In systems (A) and (B), the patterns of the catalytic effect of copper (II) ion seem to resemble each other. The effect of the addition of equimolar or 0.01 molar copper (II) ion to cysteamine was remarkably observed at $\mathrm{pH} 3.9$ (equimolar) and $\mathrm{pH} 7.4$ (0.01 mole) in contrast to the generally known tendency, that is the oxidation of thiol to disulfide is enhanced in alkaline medium (Fig. 3 (A)). This fact may suggest that the reaction involves the formation of a complex in acid and neutral medium as an intermediate and can not be explained simply by the oxidation reaction. In system (B), the hydrolysis of glutathione seems to be also catalyzed by copper (II) ion. The hydrolysis was remarkable at $\mathrm{pH} 7.4$ and 10.9 with equimolar amount of copper (II) ion (Fig. 3 (B)). In system (B), similarly to the case of 
TABLE II. Catalytic Effect of Copper (Ratio of Amount of Mixed Disulfide with Copper to that without Copper)

A) Cysteamine-Cysteine

\begin{tabular}{|c|c|c|c|c|c|c|c|c|c|c|}
\hline \multirow{2}{*}{$\begin{array}{l}\text { System } \\
\mathrm{pH}\end{array}$} & & \multicolumn{3}{|c|}{$\begin{array}{l}\text { Cysteamine cysteine } \\
\text { equimolar } \mathrm{Cu}(\mathrm{II})\end{array}$} & \multicolumn{3}{|c|}{$\begin{array}{l}\text { Cysteamine cysteine } \\
0.1 \text { molar } \mathrm{Cu}(\mathrm{II})\end{array}$} & \multicolumn{3}{|c|}{$\begin{array}{l}\text { Cysteamine cysteine } \\
0.01 \text { molar } \mathrm{Cu}(\mathrm{II})\end{array}$} \\
\hline & & 3.9 & 7.4 & 10.9 & 3.9 & 7.4 & 10.9 & 3.9 & 7.4 & 10.9 \\
\hline \multirow{3}{*}{$\begin{array}{l}\text { Reaction } \\
\text { time (hr) }\end{array}$} & 0.5 & 2.16 & 1.69 & 0.68 & 1.83 & 2.90 & 1.22 & 0.97 & 2.73 & 1.20 \\
\hline & 2 & 1.32 & 0.99 & 0.29 & 1.42 & 2.35 & 0.67 & 1.03 & 3.22 & 1.15 \\
\hline & 24 & 1.15 & 0.26 & 0.10 & 1.24 & 0.61 & 0.65 & 0.28 & 0.64 & 0.51 \\
\hline
\end{tabular}

B) Cysteamine-Glutathione

\begin{tabular}{|c|c|c|c|c|c|c|c|}
\hline \multirow{2}{*}{$\begin{array}{r}\text { System } \\
\mathrm{pH}\end{array}$} & & \multicolumn{3}{|c|}{$\begin{array}{l}\text { Cysteamine glutathione } \\
\text { equimolar } \mathrm{Cu}(\mathrm{II})\end{array}$} & \multicolumn{3}{|c|}{$\begin{array}{l}\text { Cysteamine glutathione } \\
0.01 \text { molar } \mathrm{Cu}(\mathrm{II})\end{array}$} \\
\hline & & 3.9 & 7.4 & 10.9 & 3.9 & 7.4 & 10.9 \\
\hline \multirow{3}{*}{$\begin{array}{l}\text { Reaction } \\
\text { time (hr) }\end{array}$} & 0.5 & $\begin{array}{c}1.660 .14^{a)} \\
1.80\end{array}$ & $\begin{array}{l}2.15 \quad 0.33^{a)} \\
2.48\end{array}$ & $\begin{array}{c}\left.0.800 .89^{a}\right) \\
1.69\end{array}$ & 1.57 & $\begin{array}{l}2.100 .05^{a)} \\
2.15\end{array}$ & $\begin{array}{c}1.390 .10^{a)} \\
1.49\end{array}$ \\
\hline & 2 & $\begin{array}{c}2.830 .21^{a)} \\
3.04\end{array}$ & $\begin{array}{c}1.000 .36^{a)} \\
1.36\end{array}$ & $\begin{array}{l}0.211_{1.55^{a)}} \\
1.76\end{array}$ & 1.60 & $\begin{array}{c}1.090 .04^{a)} \\
1.13\end{array}$ & $\begin{array}{c}0.920 .06^{a)} \\
0.98\end{array}$ \\
\hline & 24 & $\begin{array}{c}1.390 .15^{a)} \\
1.54\end{array}$ & $\begin{array}{c}0.520 .67^{a)} \\
1.19\end{array}$ & $\begin{array}{c}0.191 .70^{a)} \\
1.89\end{array}$ & 1.44 & $\begin{array}{c}1.120 .02^{a)} \\
1.15\end{array}$ & $\begin{array}{c}0.750 .14^{a)} \\
0.89\end{array}$ \\
\hline
\end{tabular}

a) Values represent those for cysteamine-cysteine mixed disulfide.

C) Cysteamine-Albumin

\begin{tabular}{lccccccc}
\hline \hline System & & \multicolumn{3}{c}{$\begin{array}{c}\text { Cysteamine albumin } \\
\text { equimolar Cu(II) }\end{array}$} & \multicolumn{3}{c}{$\begin{array}{c}\text { Cysteamine albumin } \\
0.01 \text { molar Cu(II) }\end{array}$} \\
\hline $\mathrm{pH}$ & & 3.9 & 7.4 & 10.9 & 3.9 & 7.4 & 10.9 \\
& 0.5 & 0.89 & 0.89 & 0.64 & 1.27 & 1.02 & 1.20 \\
Reaction & 2 & 1.32 & 0.84 & 0.79 & 0.85 & 1.07 & 1.22 \\
time (hr) & 24 & 0.61 & 0.92 & 0.97 & 0.89 & 1.03 & 1.19 \\
\hline
\end{tabular}

D) Cystamine-Cysteine

\begin{tabular}{|c|c|c|c|c|c|c|c|c|c|c|}
\hline \multirow{2}{*}{$\begin{array}{l}\text { System } \\
\mathrm{pH}\end{array}$} & & \multicolumn{3}{|c|}{$\begin{array}{l}\text { Cystamine cysteine } \\
\text { equimolar } \mathrm{Cu}(\mathrm{II})\end{array}$} & \multicolumn{3}{|c|}{$\begin{array}{l}\text { Cystamine cysteine } \\
0.1 \text { molar Cu(II) }\end{array}$} & \multicolumn{3}{|c|}{$\begin{array}{l}\text { Cystamine cysteine } \\
0.01 \text { molar } \mathrm{Cu} \text { (III) }\end{array}$} \\
\hline & & 3.9 & 7.4 & 10.9 & 3.9 & 7.4 & 10.9 & 3.9 & 7.4 & 10.9 \\
\hline \multirow{3}{*}{$\begin{array}{l}\text { Reaction } \\
\text { time (hr) }\end{array}$} & 0.5 & 0.20 & 0.46 & 0.74 & 0.99 & 1.52 & 1.30 & 1.29 & 1.82 & 1.50 \\
\hline & 2 & 0.24 & 0.82 & 0.41 & 0.92 & 1.65 & 0.79 & 0.99 & 1.82 & 1.02 \\
\hline & 24 & 0.31 & 0.28 & 0.22 & 0.38 & 1.10 & 0.94 & 1.31 & 0.88 & 1.10 \\
\hline
\end{tabular}

system (A), the effect of the addition of 0.01 molar amount of copper (II) ion was remarkable at neutral medium $(0.5 \mathrm{hr})$, but the effect of the addition of equimolar amount of copper (II) ion is remarkable in neutral and alkaline medium, the amount of the mixed disulfide produced by the hydrolysis being taken into account (Table II). The reaction in system (C) may be considered to be different to some extent from the reactions in systems (A) and (B), since the patterns of the effect of copper (II) in system (C) (Fig. 3 (C)) are different from those in systems (A) and (B) (Fig. 3 (A) (B)). The catalytic effect is very week with 0.01 molar quantity of copper (II) ion, and inhibitory effect with equimolar quantity was observed. In system (D), which was done as an example of the thiol-disulfide exchange reaction for the comparison with other systems, the effect of the addition of 0.01 molar copper (II) ion was remarkable 
especially in neutral medium, whereas complete inhibition was observed by the addition of equimolar copper (II) ion in any medium. As the patterns of the results in system (C) seem to resemble those in system (D), the contribution of the disulfide-thiol exchange reaction between the disulfide bonds in albumin and the thiol group in cysteamine may be relatively large to the formation of the mixed disulfide in system (C). Albumin seems to react readily with cysteamine to form the mixed disulfide even without copper (II) ion and the presence of copper (II) ion catalyzes the formation of the mixed disulfide to some extent. The fact that catalytic effect of copper (II) ion is observed remarkably with the reaction time of 0.5 $\mathrm{hr}$ in several cases is very interesting in connection with the observation that cysteamine is highly effective when it it given within $0.5 \mathrm{hr}$ before irradiation. ${ }^{3,5}$ ) As a whole, $\mathrm{pH}$ of the reaction medium and the ratio of copper (II) ion to thiol seem to have essential relation to the catalytic effect. These facts may suggest that the complex formation of these thiols with copper (II) ion is closely connected to the formation of the mixed disulfide. We have found that complex formation of cysteamine with copper (II) ion is complicated and unstable mixed valence copper chelate of cysteamine is produced under certain reaction condition, ${ }^{\mathbf{1 1})}$ as a result of the cocurrence of the redox reaction and the complex formation between cysteamine and copper (II) ion. This characteristic complex formation of cysteamine with copper (II) ion may be considered to have the connection to the mechanism of the catalytic effect of copper (II) ion.

It is difficult to explain the reaction mechanism and to presume the structure of the intermediate copper complex in this reaction. However, at present stage, the following speculation seems to be reasonable on the basis of the results obtained previously on the complex formation of cysteamine with copper (II) ion. ${ }^{11)}$ When cysteamine was mixed with other thiol compound in the presence of copper (II) ion, mixed valence mixed ligand complex (II in Chart 1) may be formed, together with the mixed valence complex ( $\mathrm{I}$ in Chart 1 ) which was reported previously, ${ }^{11)}$ by the coordination of thiol compound to vacant coordination sphere in complex I. The complex II which may be considered as an intermediate may be readily decomposed to form the mixed disulfides. In the previous study, ${ }^{11}$ ) it was found that cysteine does not form the mixed valence complex corresponding to the complex I in Chart 1 in neutral and weakly acid medium where the catalytic effect of copper (II) ion was remarkable. The following results of the measurement of absorption spectra seem to be a support for this consideration for the reaction mechanism. The solution which was prepared by mixing cysteamine with copper (II) ion with the ratio of 2 to 1 , showed an absorption maximum (shoulder) at $420 \mathrm{~m} \mu$, and the solution of the mixture of cysteine and copper (II) ion with the same ratio showed an absorption maximum (shoulder) at $440 \mathrm{~m} \mu$, whereas, the solution of the mixture of cysteamine, cysteine and copper (II) ion with the ratio of 1 to 1 to 1 produced a red-violet color with an absorption maximum (shoulder) at $460 \mathrm{~m} \mu$ both at $\mathrm{pH}$ 7.4 and 10.9 (Fig. 4). This red-violet color may be regarded as a characteristic of the mixed valence copper complex.11,15-17) As shown in Fig. 4, absorbance at $460 \mathrm{~m} \mu$ of the solution of $\mathrm{pH} 7.4$ lowers rapidly. From these observations, it may be possible to presume the mixed valence mixed ligand complex (II in Chart 1) as an intermediate under the experimental condition where the catalytic effect of copper (II) ion was remarkable, as the result of the complex formation which occurs in parallel with the redox reaction. On the basis of the above-mentioned discussion, the reaction mechanisms in the various systms may be tentatively described as shown in Chart 1 . In system (B), the mechanism of the formation of the mixed disulfide may be essentially the same as in system (A), but the mechanism of the hydrolysis of glutathione by copper (II) ion is not clear. In system (D), when copper (II) ion is present

15) I.M. Klotz, G.H. Czerlinski and H.A. Fiess, J. Am. Chem. Soc., 80, 2920 (1958).

16) U. Takeuchi, Nippon Kagaku Zasshi, 83, 292 (1962)

17) Y. Sugiura and H. Tanaka, Chem. Pharm. Bull. (Tokyo), 18, 368 (1970). 
in 0.01 molar ratio to cystamine and cysteine, it may be assumed that copper (I) ion produced from copper (II) ion by the reduction with cysteine cleaves disulfide bond of cystamine and mixed valence copper complex of cysteamine is formed and then cysteine reacts with this complex to form the mixed disulfide finally through the intermediate complex as mentioned above. In addition, catalytic effect of copper (II) ion was confirmed by the fact that the addition of equimolar or more various chelating agents such as EDTA, $o$-phenanthroline and
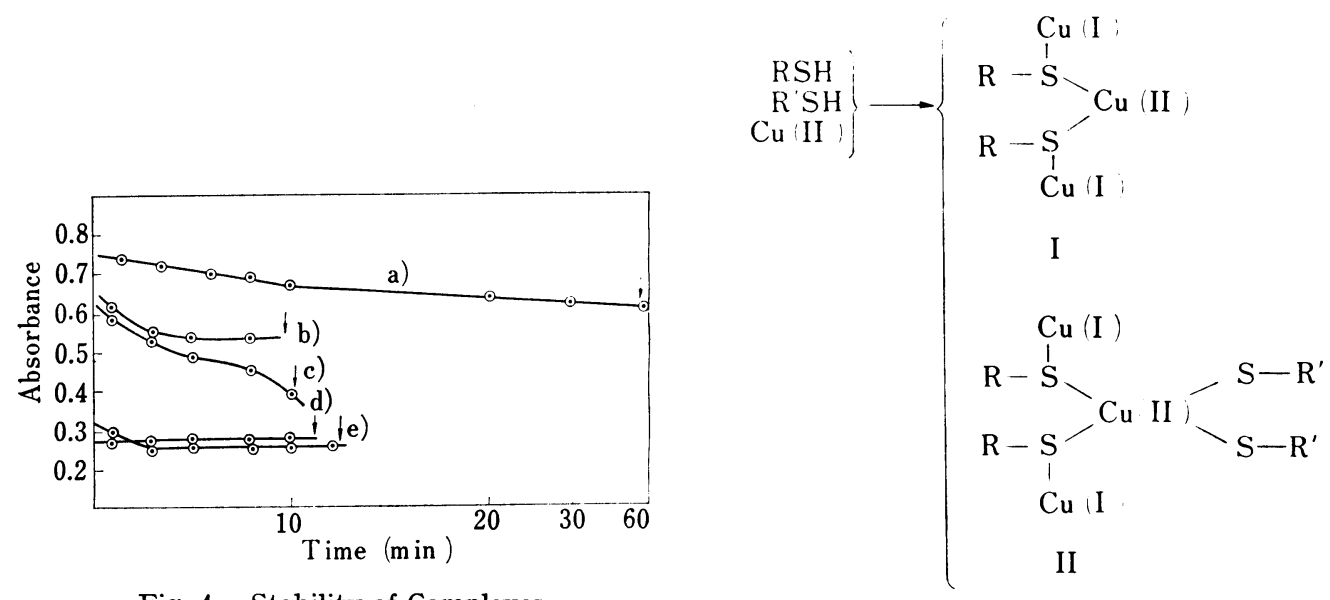

Fig. 4. Stability of Complexes

a) cysteine: cysteamine: $\mathrm{Cu}(\mathrm{II})=1: 1: 1(\mathrm{pH} 10.9, \lambda=460$ $\mathrm{m} \mu(\mathrm{sh}))$

b) cysteine: $\mathrm{Cu}(\mathrm{II})=2: 1(\mathrm{pH} 10.9, \lambda=440 \mathrm{~m} \mu(\mathrm{sh}))$

c) cysteamine: $\mathrm{Cu}(\mathrm{II})=2: 1 \quad(\mathrm{pH} 10.9, \lambda=420 \mathrm{~m} \mu(\mathrm{sh}))$

d) cysteine: cysteamine: $\mathrm{Cu}(\mathrm{II})=1: 1: 1(\mathrm{pH} 7.4$, $\lambda=460 \mathrm{~m} \mu(\mathrm{sh}))$

e) cysteine: $\mathrm{Cu}(\mathrm{II})=2: 1(\mathrm{pH} 7.4, \lambda=440 \mathrm{~m} \mu(\mathrm{sh}))$ concentration of $\mathrm{Cu}(\mathrm{II})=5 \times 10^{-3_{\mathrm{M}}}$

$\downarrow$ : Decolorization or precipitation occurred by the decomposition of the complex.

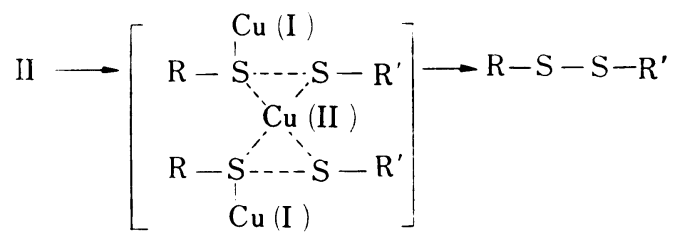

$\mathrm{RSH}=$ cysteamine $\mathrm{R}$ 'SH $=$ thiol compound

Chart 1

TABLE III. Effect of Various metal Ions on the Formation of Cysteamine-Cysteine mixed Disulfide

\begin{tabular}{ccc}
\hline & \multicolumn{2}{c}{ Cysteamine-cystein mixed disulfide (\%) } \\
Metal ion & $0.5 \mathrm{hr}$ & $\mathbf{2} \mathrm{hr}$ \\
\hline & 31.5 & 35.6 \\
$\mathrm{Mg}(\mathrm{II})$ & 34.0 & 33.3 \\
$\mathrm{Cr}(\mathrm{III})$ & 31.6 & 27.1 \\
$\mathrm{Mn}(\mathrm{II})$ & 30.3 & 44.7 \\
$\mathrm{Fe}(\mathrm{III})$ & 50.0 & 51.1 \\
$\mathrm{Co}(\mathrm{II})$ & 26.2 & 57.1 \\
$\mathrm{Ni}(\mathrm{II})$ & 36.2 & 41.0 \\
$\mathrm{Zn}(\mathrm{II})$ & 34.1 & 43.2 \\
$\mathrm{Cd}(\mathrm{II})$ & 38.7 & 39.2 \\
$\mathrm{Hg}(\mathrm{II})$ & 33.3 & 43.1 \\
$\mathrm{Cu}(\mathrm{II})$ & 58.1 & 52.6 \\
\end{tabular}

cysteamine: cysteine: metal ion $=1: 1: 0.01$ concentration of metal ion $=1 \times 10^{-4} \mathrm{M}$ pH 7.3 (tris buffer) 
$\mathbf{x}$-ascorbic acid to the amount of copper (II) ion inhibited completely the catalytic effect of copper (II) ion. Only iron (III) was found to have catalytic effect to some extent to the formation of the mixed disulfide among various metal ions tested (Table III). The effect of iron (III) ion has also been reported in the formation of the mixed disulfide between L-cysteine and D-penicillamine. ${ }^{18}$ ) The mechanism of the effect of iron (III) has not been clarified but it seems to be different from that in copper (II).

In conclusion, the results obtained here may give a support to the possibility that chelating ability of cysteamine offers some contribution to its radioprotective activity through the effect towards the formation of the mixed disulfide. 